\section{RESEARCH VESSEL ARGO-MAINE}

\section{By David W. Townsend}

THEAssociation for Research on the Gulf of Maine (ARGO-Maine), formed in the fall of 1984 , is a consortium of the principal academic, private and government marine research organizations in the State of Maine. Its member institutions include the Bigelow Laboratory for Ocean Sciences, the Maine Department of Marine Resources, the Maine Geological Survey, Maine Maritime Academy, and the University of Maine. ARGO-Maine's fundamental mission is to stimulate and facilitate scientific research on the Gulf of Maine.

In 1987 ARGO-Maine was awarded the R/V Cayuse by the National Science Foundation. The ship, which arrived from Moss Landing, California, in October of 1987, is the only U.S. oceanographic research vessel based in the Gulf of Maine. Renamed the R/V ARGO-Maine, she is owned by Maine Maritime Academy, which operates the vessel on a non-profit basis on behalf of the ARGO-Maine institutions.

The ARGO-Maine was built in 1968 as an oceanographic research vessel. Originally named the R/V Cayuse after an American Indian tribe, she was assigned to Oregon State University as part of the National Science Foundation's (NSF) UniversityNational Oceanographic Laboratory System (UNOLS) fleet. In 1977 she was trans-

David W. Townsend, Bigelow Laboratory for Ocean Sciences, McKown Point, West Boothbay Harbor, ME 04575

Editor's Note: This new section of the magazine will be used to highlight research vessels and other major research tools that are available for use by oceanographers. The purpose is not to advertize institutions or their facilities, but to publicize the availability and costs of critical or specialized research equipment. The intent is to encourage the most efficient and costeffective use of major facilities. Institutions and individuals are encouraged to submit brief descriptions of appropriate facilities, including an estimate of costs and names of persons to contact for detailed information.

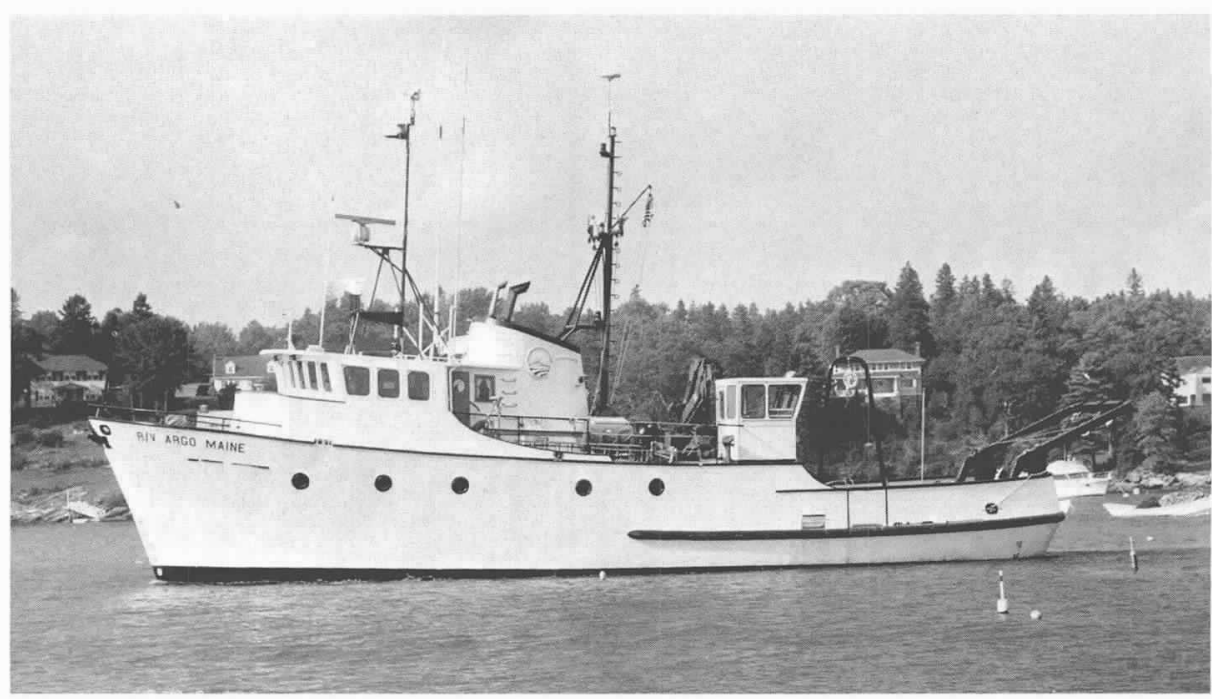

ferred to Moss Landing Marine Laboratories of San Jose State University. Responding to recent use patterns, UNOLS reassigned the R/V Cape Florida (renamed Point Sur) from the University of Miami to Moss Landing to replace the smaller Cay-

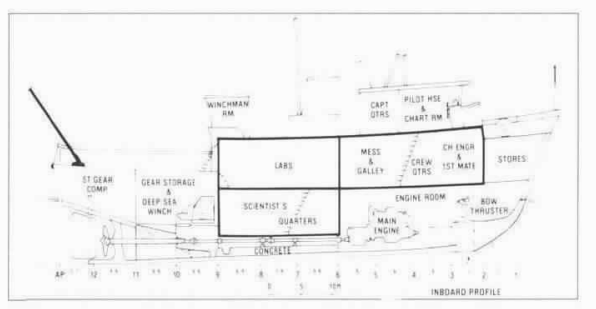

\begin{tabular}{|c|c|}
\hline \multicolumn{2}{|c|}{ R/V ARGQ-MAINE SPECIFICATIONS } \\
\hline Length & 80 feet \\
\hline Beam & 24 feet \\
\hline Draft & 10 feet \\
\hline Displacement & 173 tons \\
\hline Maximum Speed & 10 knots \\
\hline Cruising Speed & 9 knots \\
\hline Minimum Speed & 0.5 knots \\
\hline Range & 4,500 miles \\
\hline Endurance & 20 days \\
\hline Crew & 5 \\
\hline Scientific Berthing & 10 \\
\hline Dry Lab Area & 187 sq. feet \\
\hline Wet Lab Area & 170 sq. feet \\
\hline After Deck Area & 400 sq. feet \\
\hline Propulsion & $\begin{array}{l}\text { Single screw with bow } \\
\text { thruster }\end{array}$ \\
\hline Electrical Power & $\begin{array}{l}\text { Two } 60 \mathrm{kw}, 125 / 208 \mathrm{v} 3 \mathrm{ph} \\
60 \text { cy generators; } 120 \mathrm{v} 1 \\
\text { ph available throughout } \\
\text { vessel }\end{array}$ \\
\hline Navigation & $\begin{array}{l}\text { SatNav, Loran C with plot } \\
\text { ter, Gryrocompass, } \\
\text { weather FAX, speedlog } \\
\text { autopilot, radar, SSB } \\
\text { VHF, fathometers, wind } \\
\text { speed and direction }\end{array}$ \\
\hline Winches & $\begin{array}{l}\text { 4-Conductor and standard } \\
\text { hydrographic }(2000 \mathrm{~m}) \text {, } \\
\text { Deep sea Trawl }(6500 \mathrm{~m}) \text {, } \\
\text { and removeable } \\
\text { dual otter trawl winches }\end{array}$ \\
\hline Heavy Lift Equip. & $\begin{array}{l}\text { 3-ton crane, Port A-frame, } \\
\text { Stern U-frame, UNOLS tie } \\
\text { downs }\end{array}$ \\
\hline
\end{tabular}

use. In 1986 the NSF requested proposals from institutions wishing to acquire R/V Cavuse, either as a replacement for a UNOLS vessel of equal or larger size, or to acquire outright ownership.

The ARGO-Maine's present captain, Don Bradford, has served with the vessel from the time of its arrival from Oregon until he became captain of the Point Sur. The ship has had an active career as a research vessel; while on the west coast, she cruised throughout much of the North Pacific, ranging as far as the Gulf of Alaska, Hawaii and Peru. She has performed essentially all types of oceanographic tasks, including box coring, piston coring, hydrographic and plankton work, otter trawling, and deploying and retrieving moorings.

The R/V ARGO-Maine is available for both short-term and extended oceanographic research cruises in the Gulf of Maine and neighboring waters. In addition to miscellaneous items of equipment available on loan from the ARGO-Maine member institutions, the ship's equipment includes a Neil Brown Mark III conductivity-temperature-depth (CTD) probe and a 12-bottle General Oceanics Rosette sampling system. The ship can accommodate standard laboratory vans on her afterdeck. Home ports are Boothbay Harbor and Castine, Maine. Rates are presently $\$ 2200$ per 24 hour day.

For more information write or call: Philip Harman, Marine Operations Officer, Maine Maritime Academy, Box C-3, Castine, Maine 04420. 